\title{
Symbolic Form in the Pedagogical Implications of Sociolinguistics
}

\author{
Mirela Tolić \\ Department of Pedagogy, Faculty of Philosophy, University of Split, \\ Trogir, Okrug Gornji, No.2, Split \\ Tel: +385-2188-6282Ｅ-mail: mtolic@ffst.hr
}

Received: December 13, $2010 \quad$ Accepted: January 10, 2011 doi:10.5430/wje.v1n1p158

\begin{abstract}
The author with the help of analysis of symbolic forms and sociolinguistics explains the transformation of homo communicans in conscious homo symbolicum. He points out the importance of etymological analysis Cassierer's philosophy of symbolic forms and its effects in the modern understanding of sociolinguistics. It is necessary their correlation relationship for the development of critical-reflective attitude towards the accelerated development of new media...The article provides an overview of pedagogical implications in the analysis of symbols and sociolinguistics in the educational process. Sociolinguistics is analyzed in terms of its impact on the development of media pedagogy in Croatia.
\end{abstract}

Keywords: Philosophy of symbolic forms, Sociolinguistic, Manipilation, Media, Educational process

\section{Introduction}

\author{
"If you open a newspaper today, you'll find more symbols than in the Iliad and the Odyssey." \\ Friedrich Georg Junger \\ "The most understandable oft he speech is not the word itself, but sound, volume, modulation, tempo in which a \\ sequence of words is spoken..." \\ Friedrich Nietzsche
}

Media play an important role in education. New information technology (Internet: web communication, electrical media ...) changing habits and behavior of individuals, especially young and the very structure of society.The change in technical globalization through innovative media has ambivalent role (Miliša \& Tolic, 2009).

For modern educators, philosophers, sociologists and media theorists, the notion of pageantry in the process of education is the key differentiation between the ontological (the technical world of the media) and the ontic ( fictive and / or virtual appearance) approach perception of reality by young people (Osmanović, 2009). It is reasonable to say that the world of mass and new media, or so. Cyber space of culture media is constitutive for understanding reality.

The understanding of reality under the influence of mass media communications, internet and other communication technologies is very different. At the same time, that doesn't mean that originally conceived reality was directly suppressed and abolished by the media reality (Dubois, 1965). The experience of reality is largely changed because of the frequent use of new mass communication. Fiction becomes reality (Miliša \& Tolic 2009). According to this interpretation, the ontic nature of these media is based only on technology and the result is the reality of so-called "phantom world", "delivered" in the "sphere" of private space and social environment which has negative effects on consciousness and health behavior of the young (Bakaršić, 1999). Understanding of the "media philosophy", updates the ontological approach to media by the analysis of the phenomenon of "adaptive world" and a world of difference between the real and the fiction in which the transformation of man into homo communicans is visible. Theorists who define man only through a single dimension have less empirical explanations of human nature (Bakaršić, 1999). With the rise of globalization and innovative media (technologies), the human mind is not very convenient concept when human needs are more "fit" in the digital culture (Bakaršić, 1999). This analysis is essentially symbolic in a media environment where reality is replaced by fiction. According to this concept instead of a man treated as animal rationale, animal symbolicum seams to be more specifique.

Transformation of the development process from the animal rational over the homo communicans to the animal is the initial phase of understanding the dangers of digital culture and innovative media (Barthes, 1981). For that undestanding is essential to analyze etimological Cassierer's philosophie of simbolic forms and to understand its action in the contemporary understanding of sociolinguistics, which are related to the functionally pragmatic role of media in the 
process of education and socialization of children and young people.

\section{Analysis of the philosophy of symbolic forms and the theoretical background of symbols research}

Ernst Cassirer "sprayed" mind in the multitude of symbolic forms: in language, myth, art, religion, scientific expression ... For Cassirer, this is not the only cognitive apparatus that constitutes reality, but a multitude of cultural spheres that constitute the various dimensions of personality and reality.

Criticism of the mind becomes by Cassirer (Cassirer, 1985) critique of culture, which is the main task of philosophy. Cassirer analyzes the culture which is very near to structuralism in semiotics: an integrative part of a symbolic system. The task of "a philosophical systematization of the spirit" is to affect the analysis of cultural forms in its immanence and organic unity (Cassirer, 1985).

What these forms have in common is the understanding of the character, language ${ }^{1}$ and symbol. Cassirer does not use this term, but the term semiosis as defined by the American semiotician and philosopher Charles Morris (according Žanić-in) means the process in which one plays the role of a character. (Žanić, 2008).

Cassirer's philosophy can be characterized as Kantian mind broken by the multiplicity of symbolic forms (Žanić, 2008). On the other hand, the pragmatic attitude of symbolic forms in the construction of sociolinguistics (Petrović, 1989). Here we can see the necessity of the correlation relationship between sociolinguistics and philosophy of symbolic forms. This process reveals the importance of the analysis of symbols, language, character, social environment and the role of linguistic disciplines in the field of linguistic phenomena (Radovanović, 1986). Further necessity argumentation for these correlations is found in the Radovanovic's book, Marxsism and philosophie of language“, which emphasizes the development of sociolinguistics detail-oriented ideas (Radovanović, 1986). Article Marxism and linguistics deals with the appropriateness of the process, but the theoretical peak of the development process is in the analysis of the critical substantiated linguistic observations of empiricists, rationalists, modern philosophy of language, culture sociology, psychoanalysis (Freud), social psychology, and learning the basics of structural Ferdinand de Saussure², Boduena de Kurtenea, phenomenological discussion early Husserl and at the end of Ernst Caissirer’s “symbolism”, semiological study sociolinguistics.

To understand Cassirer and his philosophy of symbolic forms, it is necessary to draw a theoretical background of the symbols concept research. By the research of symbols is inevitable multidisciplinary and interdisciplinary approach. The theoretical background is based on the pedagogical implications but also the sociological results in the process of education. This is why it is necessary to give some influential authors and their contribution to the thinking and research on this subject.

Mead's symbolic interactionism "I", "Me," "Self" is inevitable in the modern conception and understanding of media manipulation by advertising propaganda that adversely affect the consciousness and behavior in children and adolescents (Miliša \& Tolic, 2009). From this aspect can be seen that Mead began to talk about the meaningful symbols. Where goods become symbols, consumption should be understood not as a consumer utility values rather than primarily as a consumer signs.

It is not just the end point of the economic, but also an exchange system, the language in which goods and property associated with the semiotic system , which, like every language, prior understanding of the behavior. No individual of self, there are only ways of using systems such as systems of language, kinship and property, through which people in different ways connected with the social order and form a sense of individuality. The problem of character and meaning is the permanent Baudrillard's obsession. The whole problem is the most thoroughly worked out, according Kalanj, in his book „Symbolic Exchange and Death ", which is considered the most important and even crucial work of Baudrillard (Trako, 2007). The character does not merely imaginary and elusive fiction than a reality that has its historical significance. Then begin characters era, who later, in the twentieth century, completly separated from its referential source. That explains Baudrillard special interest in the symbolic exchange. It explains as opposed to production, consumption and all the values of bourgeois society. In today's modern media environment, the exchange of symbols is analyzed through tvrdnju that "everything has its price and nothing has the value". All this is particularly evident in the marketing propaganda (advertising for children and youth ...), which indicates the status and / or even a style or subculture of young people (eg, make-up artist, hedonists, rockers .... etc.). Psychoanalysts, as we have already seen in Freud used the term symbolic in almost every form of emotionally colored behavior in children and adolescents. For Sapir is a symbol first and foremost is always a substitute for a direct (U.S. closely intermediating) type of behavior, from which it follows that any symbolism implied meanings that can not be derived directly from the context of experience. This aspect can be associated with the analysis of "violence in the media and violence in reality", or an escape from reality into fiction, which has disastrous consequences for the socialization of children and young people, which is explicity visible dysfunctional role of the media (Miliša \& Tolic2009). 
This aspect can be associated with the analysis of advertisements in the media and its manipulation using the aesthetic image, colors that certainly can cause condensation energy of youth and what would turn into a modern language means "escape from reality" (exemplified by online communication, Facebook, creating a false friend, an idol ... etc).

Sapir, distinguishes two main types of symbolism (Cassirer, 1985). The first of them, which he calls referential symbolism, including such forms as oral speech, writing, telegraphic means, national flags, signal flags and other symbols of organizations which have been adopted as referential purposes. The other type of symbolism is equally cost-effective and could be called condensation symbolism because he, as a condensed form of behavior replaced direct expression, allowing the discharge of emotional tension in conscious or unconscious form (exemplified by violence among their peers, that the uncontrolled consumption of video games cause violent behavior in reality). Sapir notes that in reality both forms are often connected and work together. However, the major developmental difference between two kinds of symbolism is that referential symbol increases with formal training in conscious /awareness, while condensing symbol plays "deeper roots" in the unconscious, and laid out its emotional tone of the types of behaviors and situations seem very distant from the original meaning of the symbols. In a symbolic expression, clear referential symbol, such as the national flag, associated with suppressed emotional mentality can be transformed to encourage the ego; (exemplified by political propaganda, indoctrination and manipulation of the media, through advertising, newspaper for young people, video games ..) . Then it can be said to be "born" symbols that Sapir said to have special power, because the unconscious meanings, full of emotional power, are rationally interpreted, as a pure reference (Trako, 2007). Therefore, Cassirer is primarily engaged in character, and its actual development and the formation of the various fields of culture (Cassirer, 1985). The power and effect of mediating signs would remain secret if they didn't, ultimately, would have had roots in a genuine spiritual process which belongs to the consciousness. To better explain his theory, Cassirer says outspoken voice can become the holder of a purely intellectual meaning only if we assume that the primary function of marking is present and active before the individual character is produced, so this producing in itself does not create meaning, but it generalizes and applies only to special cases. In this context are visible to the theoretical structure of French linguist F. de Saussura and his structural linguistics from which a modern theorist N. Luhmann developed his own system of communication and Stuart Hall Encodig/Decoding System. Cassirer recognize for the first time that exist a real difference in the symbolic function between spiritual and sensual awareness. When the sign would not be anything else than a repetition, in a self contained, the individual content of observations or play, then do not make it clear what he really is (Cassirer, 1985). About all of them can ultimately be said that their value does not consist so much in what they retain from the sensory-specific individual content and his immediate presence, as in fact what are theyrepressed and ignored from this immediate existence (Trako, 2007). For the modern understanding of linguistic analysis and Cassierer's philosophy of symbolic forms is necessary to understanding the contemporary role of sociolinguistic.

\section{Reflections of sociolinguistics in the modern conception of media pedagogy}

Sociolinguistic ${ }^{3}$ - linguistic discipline that studies the social aspect of language. Sociolinguistics is a linguistic discipline that studies the use of language as a means of communication in the socio-cultural context. It examines the impact of social and cultural factors on language. As a scientific discipline it covering studies of the relationship between linguistic and social phenomena(Radovanović, 1986). It examines the language of the individual within the collective (mikrosociolinguistic), but the language ${ }^{4}$ of the collective, or parts thereof (makrosociolinguistic) - in other words linguistic expression - speaking behavior of individuals in the collective and linguistic expression, speech and behavior of the collective. Sociolinguistics is more interested in the use of language rather than linguistic knowledge, and in the field of linguistic knowledge about the art of communication (language use) than for knowledge of code (the linguistic system), the knowledge of the rules governing the selections and use of linguistic resources (Radovanović, 1986). Sociolinguistics in greater or lesser extent overlaps with pragmatics. Pragmatics deals with the use of language in communication. It examines linguistic resources whose meaning can be understood only in the proper context. Pragmatics is the study of communication resources about the education. With this structure is an important aspect of semiotics. Semiotics is a general science of signs and symbols, and especially the study of nature, relationships and roles of linguistic signs. In this sense, it "fit" with semiotics. The system of signs in the communication process is associated with the theoretical basis of Nichols Luhmann (1991) since semiotics is divided into logical syntax, logical semantics and logical pragmatics. The first examines the relationship among characters themselves, other interrelations between signs and their semantic content, and the third examines interrelations between the sign and the users of the signs. The character is, in fact, the intellectual tools to evaluate the facts of existence (Thomas Sebeok), and technological advances - such as phones, televisions, computers and the Internet - introduced with the electronical way the variety by production of the characters.

The study of signs today focuses primarily on the logic of communication and disclosure of "codes" that form the 
background of diverse cultural phenomena. The study of the signs system again has strengthened already estalbished disciplines (semiotics of the media, the science of the media) and to help create new ones, such as the study of communications, media and culture (media pedagogy, communications sciences, mediology).

For this understanding is needed of the pedagogical analysis of the symbolic interactionism theorist G.H. Mead and referential and condensational symbolism by E. Sapir's. Specifically, sociolinguistics is approached to language primarily from the side of his interaction, or communication functions in the inescapable importance of the role of symbolic interactionism which is the most recognizable "I", "Me" and "Self" through the exchange of symbols in the interactional socializational process.

In this context, we analyze the hierarchy of the educational process: communication, interaction and context of the situation where we examine the norms of communication of the individual in a social environement. Sociolinguists, dealing with the language as a code, give the most attention to the role of context in the processes of the understanding in the speech community, situation and event (Radovanović, 1986).

The language is often defined as a system of the characters that serve as communication which is associated with the Encoding / Decoding System \& Stuart Hall's (1987) and Nicholas Luhmann (1991).

Roman Jakobson, one of the most prominent linguists of the twentieth century, takes the analysis from the communication theory which decides six language functions, and so that each element of the communication process corresponds to one of these functions. We define the dominant function of each message (specifically the media message, because the media are carriers of symbolic messages), but this is not the only function of these messages, but comes with other, more or less prominent functions. Jakobson notes that the verbal structure of messages is always caused with the dominant function of the message. Here it is recognized aesthetic function that is associated with emotional personality structure, which in particular, youth and children can have negative consequences, if is dysfunctional character (Jakobson, 1999). In any communication event, and so in every speech event, which is a communication event par excellence, the sender sends a message to the recipient (recipient, addressee) about a particular subject, which Jakobson called context. Messages must be on code that is common to the recipient (which encodes the message) and the sender (which decodes the messages), othetwise communication is impossible.

Analysis of the Sturat \& Hall Encoding/Decoding System and understanding Luhmann concept of communication can be decodeda manipulatives media messages that media transmit and disclose intentions of the political indoctrination while in the process of the education developes reflexively-critical attitude towards the media as carriers of symbolic messages. Recall, that each message starts in a channel (it can be air or a wire or electronic impulses given by the media).

sender----------- channel ----------- message --------- channel-------- receiver

From this context of sociolinguistics can develop five functions: 1 referential function (denotative, cognitive) refers to the subject, the relationship between the message and the officer, 2 expressive (emotional) function indicates the orientation on the message issuer. This function expresses the speaker's subjective attitude (children and young people) to the message, she focused on the speaker's expression of emotion (real or that he wants to send with the message), 3 Fatick function is directed to the contact, to the channel. It serves primarily the establishment, extension or cancellation of communication, 4 metalinguistic function indicates the direction of the message at the code, 5 poetic (aesthetic) function is defined as targeting messages to itself, where the message stops being a means of communication and becomes a target.

Scheme of the five language functions, included in the scheme of the five elements of communication process, therefore it will look like this: metalinguistic function - expressive (emotional)- poetic-, conative-factual referential. With these functions are sometimes allocated ludic function, game function, play with language, as is often represented in different genres - from nursery rhymes and riddles, from comic books and advertisements, most in the manipulation of the media. All six functions are correlativ related, to explain the transformation of the development process from animal rational, over communicans homo into homo simbolic. When de Saussure (1987) anticipated the development of science that would study the functioning of signs in social life and called it semiotics, he is considered that the linguistic is only a part of such a science. Therefore, to understand such a process must strive for understanding E. Casier philosophy of symbolic forms. In addition, for this founder of modern linguistics is the natural language the sign system par excellence, and linguistics can serve as a model of semiotics which together have given rise to the developmental understanding of the transformation process from communicans homo to the homo 
symbolicumsu. Starting from these assumptions, the semiotic will again be considered part of linguistics, and to what extent "that he took upon himself the great semantic unit of exposure, so would not affect the unity of research that are ongoing in antropology, sociology, psychology and stylistics in relation with the notion of meaning.” (Barthes, 1981).

Many theorists assume that the science of signs kind of interscience that permeates and connects a variety of scientific disciplines, including sociolinguistics. In one of the most recent encyclopedic view of semiotics is this definition: "As human beings, we can decide not to eat or drink, do not talk or communicate, or perhaps even that we do not live, but as long as we live, however we can not choose to does not convey 'meaning' the world around us. "Semiotics', in the broadest sense, is to study basic human activity of creating meaning." The characters' are all types of elements - verbal, nonverbal, natural, artificial, etc. - that carry meaning" and from which „gives bitrh“ symbol and if it grows into a status symbol (Nokia, Mercedes) can have a devasting message to young children in the educational process and the modern notion of understanding the communication process (Miliša \& Tolic, 2009). The characters in the narrow sense are a matter of convention. For symbols that are "born" from the sign are, in turn, motivated characters, motivated to some kind of process and / or function. But when it comes to games, then it is in the forefront their ludic functions with sociolinguistics aspect (among other things, a man is a homo ludens - he is playing with the language, comes up with children's games and games for adults, he play when he took some roles in the family, society...) (Bakaršić, 1999). Therefore socilinguistic is understood as a system of symbolic systems (Cassirer, 1985) that are simultaneously in socializational-educational process. In other words, sociolinguistic has a pragmatical (educational) level and function. It establishes syntactic-semantic, textual and lexical differences between the styles of science, philosophie, politics, technology, media, pedagogy, administration, journalism, etc. (Radovanović, 1986). It also research a situational differences (creates stylistic differences between the situations in which a voice representative use his language as a communication and creative instrument), theme (style differences arise according to the content), individual (resulting specific characteristics of each individual speaking representatives), the territorial (expressed through the linguistic differences between individual areas within the territory of one language) and social (reflecting social differences between individual social within the speech community, ampng social classes, structures and groups) (Radovanović, 1986).

\subsection{Sociolinguistics and media pedagogy}

The media are the carriers of the communication process, media pedagogy with the sociolinguistic framework of semiotics, and philosophy of symbolics form should be interpreted: the spoken language, books, pictures, photos, TV, $\mathrm{CD}$, computer, internet, as well as information and communication "tools" for practical use. Postmodern society has been accompanied by rapid development of digital globalization. Schmidt distinguishes four applications of modern media: 1 media as the "code", an analytical tool of communication; 2 media as a message; 3 media as "technical means" for the production of texts (eg, computer ...) and 4 media as the fastest "carriers" of media and offer information. It is a known fact that the media are all very important role in the socialization of the young generation, but also manipulation. Media pedagogy is in important connection with the linguistic discipline- sociolinguistic and it try to find a manipulative and educational messages in the media. Hug, T. (2007) has set the following questions: 1 How communication is changing among young people in the family, school, social environment among young people while using innovative media? 2 What are the consequences trivial offer media (digital media ...) and what forms are shown as symbols? ${ }^{5}$ As a symbol, a sign that the communication media? And 3 in which the (important) aspects of media educators should rely on the development of media competence? Media pedagogy developed within the educational sciences as a reaction to the (pedagogical) consequences of rapid development (innovative) media in the twentieth century.

Theoretical development of media pedagogy has not yet been fully formed. This young discipline has different areas of science (educational sciences, sociology, communication sciences ...) that is why there are a diverse perspectives and interpretations about the media: media science, media, semiotics, communication theory, mediology, media psychology and sociology of the media (Miliša \& Tolic, 2009). It has so far failed to discern the fundamental (theoretical) point of view and practices.Media pedagogy based on the hypothesis that every man lives in the symbolic world. These symbols should be decoded to education were encouraging. The symbolic world can be understood with the help of semiotics of the media, through a system of "signifie"6and "signifiant (signifier). "Marked" in this context, the media-object, a "marker" for the individual who assumes the role of recipient information. In education the values are tanning in a central notion and the signs and symbols in this process have a pedagogical role. To decoded integrated signs and symbols, important role has of media pedagogy. Sociolinguistics suggest that language is the most appropriate media for abuse signs and symbols of indoctrination (especially political), and media manipulation. With this distinction does not proceed from the content analysis but from the analysis of decision-making process. Reflection refers to the individual, to the signifikant. The relationship between advertising and promised is a relationship of the creating of new needs, so 
substitute the imposed requirements. It is these requirements imposed on individuals giving apparent image that indicates that the individual is the one who decides. This belief is often at odds with reality. Examples are given to indicate the necessity of cooperation of sociolinguistics, philosophical and symbolic forms of media pedagogy.

\section{Conclusion}

It is reasonable to say that the world of mass and new media, or so. Cyber space of culture media significantly changed the experience of reality. Fiction becomes reality. According to this interpretation, the ontic nature of these media is based only on technology or technical matrix mediatization, mediatic mediation images, resulting in the expansion of media manipulation of the consciousness and behavior of youth. Transformation of the development process from animal rationale, over communicans homo-conscious to a homo symbolicuma is the first analytical phase of the analysis of digital culture and innovative media. To transform this understanding is essential to know the essence Cassierer's philosophy of symbolic forms and to understand its action in the contemporary understanding of sociolinguistics, which are related to pragmatic-pedagogical role of media in the process of education and socialization of children and young people. In this context begins to realize the necessity of the correlation relationship between sociolinguistics and philosophy of symbolic forms. This process reveals the importance of the analysis of symbols, language, character, social environment, individual is, the interaction of linguistic discipline with pedagogical aspects in the development of children and young people. Meead first to reveal the application of the theory of symbolic interactionism. This aspect can now be linked with the analysis of advertisements in the media and its manipulation through images, colors that certainly can cause condensation energy of youth and what would turn into a modern language means "escape from reality" (exemplified by online communication, Facebook, creating a false profile, idols, etc ...). Sociolinguistics is approached to the language primarily from its interaction, or communication functions in the inescapable importance of the role of symbolic interactionism which is the most recognizable "I", "Me" and "Self" through the exchange of symbols in the interactional socialisation process. In this context, we analyze the hierarchy of the educational process: communication, interaction and context of the situation where the norms of individul communication are examined in a social setting. The media are carriers of the communications process, media pedagogy with the sociolinguistic framework of semiotics and the philosophy of symbolic forms should be interpreted: the spoken language, books, pictures, photos, TV, CD, computer, internet...as information and communication „tools“ for practical use. Media pedagogy tries to uncover the educational and the handling messages in the media. Social linguistics suggests that media language is also good for abuse signs and symbols in the indoctrination (especially political), and media manipulation.

\section{References}

Barthes, R. (1981), Das Reich der Zeichen. Frankfurt/Main: Suhrkamp.

Barthes, R. (1989), Carstvo znakova. Zagreb: August Cesarec.

Bakaršić, M. K (1999), Lingvistička stilistika, Society Institute, Center for Publishing Development Electronic Budapest, Hungary: Publishing Program Október 6. u. 12, H-1051.

Berkhofer, R; F., Jr. (1995), Beyond the Great Story. History as Text and Discourse.- Cambridge, Massachusetts. London, England: Harvard University Press.

Birch, D. Stylistics (1994), The Encyclopedia of Language and Linguistics. Vol. 8. (pp. 4378-4383). Ed. R.E. Asher.- New York, Seoul, Tokio: Pergamon Press, Oxford.

Burton, D. (1980), Dialogue and Discourse. A sociolinguistic approach to modern drama dialogue and naturally occuring conversation.- London, Boston and Henley: Routledge \& Kegan Paul.

Burger, H. (2003), Čovjek, simbol i prafenomeni. Zagreb:Bibliotheka Homo Absconditus.

Cassirer, E. (1985), Filozofija simboličkih oblika, I-III. Novi Sad: Dnevnik.

Cassirer, E. (2000), Prilozi filozofiji jezika. Zagreb: Matica hrvatska.

Croce, B. (1991), Estetika kao znanost izraza i opća lingvistika. Zagreb.

Downes, W. (1994), Register in Literature.- In: The Encyclopedia of Language and Linguistics. Vol. 7. (pp. 3509-3511). Oxford, New York, Seoul, Tokio: Ed. R.E. Asher.Pergamon Press.

Dubois, J. (1965), Grammaire structurale du francais: nom et pronom. Paris: Liberairie Larousse.

Mead, G. H. (2003), Um, osoba i društvo, Naklada Jesenski i Turk, Zagreb: Hrvatsko sociološko društvo.

Miliša, Z., Tolić, M. (2009), a, Određenje medijske pedagogije s komunikacijskog aspekta, MediAnali 4, Sveučilište u 
Duborvniku.

Miliša, Z; Tolić, M; Vertovšek, N. (2009), Mediji i mladi- prevencija ovisnosti o medijskoj manipulaciji. Zagreb: Sveučilišna knjižara.

Osmanović, E. (2009), Demokratičnost. WWW- komuniciranja. Sarajevo: Friedrich Ebert Stiftung.

Pierce, J. (1962), Symbols, Signals, and Noise. London: Hutchinson.

Petrović, S. (1989), Umjetnost i simboličke forme. Sarajevo: Narodna biblioteka BIH.

Radovanović, M. (1986), Sociolingvistika. Novi Sad: Književna zajednica.

Trako, T: (2007), Simbol ruke. Razmatranja o pojavi i značaju simbola ruke u kontekstu svakodnevne komunikacij, Soc. ekol. Zagreb, Vol. 16 (2007), No. 1 (35-57).

Wardhaugh, R. (1996), An Introduction to Sociolinguistics. Oxford, Basil Blackwell, 1987. Widdowson, H.G. Linguistics.Oxford University Press.

Young, R. E., Becker, Alton L., Pike, Kenneth L. (1970), Rhetoric: Discovery and Change.- New York, Chicago, San Francisco, Atlanta: Harcour, Brace \& World, Inc.

Yankah, K. (1994), Rhetoric: Anthropological Perspectives.- In: Asher R.E. (ed.) The Encyclopedia of Language and Linguistics. Vol. 8. (pp. 3568-3571), Oxford, New York, Seoul, Tokio: Pergamon Press.

Žanić, J. (2008), Semiozom stvoren svijet:Cassirer - Goodman, Filozofijska istraživanja, 109 God. 28 Sv. 1 (107-116), Zagreb.

\section{Notes}

Note 1: Each language has an endless number of possible variations. The human ability to understand and use a creative power of symbolic actions. The definition of linguistics as a discipline has a strong symbolic function (Radovanovic, 1986).

Note 2: Ferdinand de Saussure (Geneva, 22 November 1857th - Vufflens-le-Château near Morges, 22 February 1913.) Is a Swiss linguist who founded their preferences modern linguistics and gave the basis for European structuralism, linguistic direction, which developed the twenties and thirtiesthe 20th century. The book Cours de linguistique générale (Course of general linguistics) published after his death, students using the notes from his lectures. They were Charles Bally and Albert Sechehaye. Saussure's linguistics, and ordered the case said that this language, explaining without distinction of language and speech. According to him the subject of a science must be a system, a language that is. The aim of the general linguistics, as de Saussure see, first set aside linguistics in the narrow sense of grammar, philology and comparative-historical linguistics, ie, a strictly defined area of its work, and then give a definitive and exhaustive list of all languages. Languages are studied as a structure, it will.Finally, in the language, according to de Saussure, there are differences. It is the view of language as a system, structure, what was later developed by structuralism. By the way, the task of linguists is studying the language as a system.

Note 3: Sociolinguistics is a relatively young discipline (Radovanovic, 1986).

Note 4: Une définition linguistique de la langue précise que c'est un système de signes doublement articulés, c'est-à-dire que la construction du sens se fait à deux niveaux d'articulation. On trouve tout d'abord celui des entités signifiantes (morphèmes et lexèmes, ou monèmes) formant les énoncés puis celui des unités distinctives de sens (phonèmes) formant les unités signifiantes. Ces deux niveaux d'articulation déterminent les premiers niveaux de la description linguistique : phonologie, morphologie et syntaxe. André Martinet précise que l'ordre de description est nécessairement inverse de l'ordre de perception ou d'usage de la langue: la description commence par le deuxième niveau d'articulation (les phonèmes) pour aller vers le premier (la combinatoire des unités signifiantes). On distingue généralement la langue (système de signes) et le langage (faculté humaine mise en œuvre au moyen d'un tel système). La langue doublement articulée n'est qu'un langage parmi d'autres, que rien ne doit privilégier: la faculté de langage est aussi mise en œuvre par d'autres systèmes de signes, comme le geste, le dessin, le vêtement, etc. La linguistique, comme science du langage au sens strict, est donc nécessairement englobée dans une discipline aux objets plus nombreux: la sémiologie ou sémiotique, science générale des signes et de la signification. On distingue également, depuis Ferdinand de Saussure, la langue et la parole (c'est-à-dire l'utilisation effective du système de la langue par les locuteurs) (Dubois, 1965).

Note 5: The meanings of things or objects are their real properties. When we use the symbol, we refer to the meaning of things. Symbols represent the meanings of those things or objects that have meaning and they are some parts of the experience that show, or indicate, or represent other parts of the experience (Mead, 2003).

Note 6: This term is often equated with the meaning (Mead, 2003). 